\title{
大腸癌再発例の臨床的検討
}

\begin{tabular}{|c|c|c|c|c|c|c|c|}
\hline & & & 贵浜市立 & 第 2 外 & & & \\
\hline 池 & 秀之 & 大木 & 繁男 & 大見 & 良裕 & 过仲 & 康伸 \\
\hline & 滋 & 飯田 & 明 & 城 & 俊明 & 山岡 & 博之 \\
\hline & 薫 & 大出 & 直弘 & 土屋 & 周二 & & \\
\hline
\end{tabular}

\section{CLINICAL STUDIES ON RECURRENCE OF COLORECTAL CANCER}

\author{
Hideyuki IKE, Shigeo OHKI, Yoshihiro OHMI, Yasunobu TSUJINAKA, \\ Shigeru TAJIMA, Akira IIDA, Toshiaki JYO, Hiroyuki YAMAOKA, \\ Kaoru FURUSHIMA, Naohiro OHDE and Shuji TSUCHIYA
}

Second Department of Surgery, Yokohama City University School of Medicine

大腸癌根治手術後の再発の防止および早期発見による治療成績の向上を目的として治瘾手術後 3 年 以上経過例に拈ける再発について検討を行った。再発は415例中 145 例 $(34.9 \%)$ にみら約 $80 \%$ は 2 年以内, 約 $90 \%$ は 3 年以内にみられた. 再発形式は結腸癌では肝再発が半数をしめ, 直腸癌では局所 再発が最も高頻度であった. 再発後 5 年生存例は 3 例のみであり, 再発死亡例129例の平均生存期間は 11.6力月であった. carcinoembryonic antigen, computed tomography の導入により特に肝再発の切

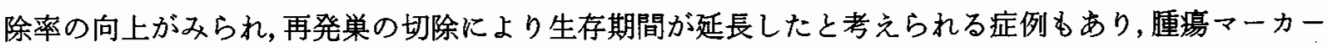
測定や画像診断などによる定期的なフォローアップを行い早期に再発を診断することが重要であると 考えられた。

索引用語 : 大腸癌の再発, 大腸癌の肝転移再発, 大腸癌の局所再発, 大腸癌再発巣の切除

はじめに

大腸癌の治療成績は向上し $60 \sim 80 \%$ 以上の 5 年生存 率が得られるようになってきているが1)，治瘾手術後 の約 $30 \% に$ 再発がみられている。これら再発例の経過 はこれまで不良であった。しかし近年, computed tomography (以下 CT), 超音波検査, 腫瘍マーカーの 検査など各種診断法の進歩により, 再切除を始めとす る治療がな打有効な比較的早期のうちに発見される例 が増加している．今回われわれは大腸癌根治手術後の 再発の防止に加觉て, 再発の早期発見による治療成績 の向上に必要な基礎的知見を得るために，自験大腸癌 再発例の145例について再発形式, 再発時期, 各因子別 再発率，再発後の生存期間などを検討したので報告す る.

$<1986$ 年 9 月 3 日受理>別刷請求先：池 秀之 =232 横浜市南区浦舟町 3-46 横浜市立大学医学 部第 2 外科

\section{I. 対象と方法}

大腸癌根治手術後の再発の大多数は 2 年から 3 年以 内にみられる2) 6). 自験例をみても約 $90 \%$ が術後 3 年 以内に再発している.そこで，今回は対象として術後 3 年以上経過例とした。

昭和 47 年 1 月から昭和 57 年 12 月までの 11 年間の横浜 市立大学第 2 外科の大腸癌737例（結腸癌 239 例, 直腸 癌 498 例)のうち, 単発の大腸癌で, いわゆる治㾤手術 をらけたものは415例 (結腸癌125例, 直腸癌290例) で ある。これらについて昭和61年 1 月の時点で再発の有 無を判定し, 原発部位, 性, 年齢, 形態分類, 進行度, 病理組織型などの項目ごとに再発率を求め, また再発 時期および再発確認後の生存期間を明らかにした。な お, 大腸癌に関する分類ならびに記載は大腸癌取扱い 規約》に従った，以上の症例における再発は結腸癌 26 例, 直腸癌119例の計145例に認められた。再発形式は 局所再発, 肝再発, 腹膜再発, 単径部リンパ節再発, 肺再発, 骨再発, 脳再発, 複数蔵器再発とした。局所 
再発としたものには手術野近傍の再発, 吻合部再発に, 確認が困難で臨床的にこれらと区別しにくい腹腔内ま たは骨盤内リンパ節からの再発む含まれている。また 一臓器の再発が確認されてから 6 カ月以内に他臓器の 再発が確認されたものは複数臓器再発例とした。再発 時期は根治手術直後から臨床的に再発が確診された時 までの期間とした。

\section{II. 結 果}

1. 大腸癌の原発部位別再発率

大腸癌治癒手術後 3 年以上経過例の再発率は $34.9 \%$ であった。また結腸癌では $20.8 \%$ ，直腸癌では $41.0 \%$ で，直腸癌の方が再発率が有意に高かった，原発部位 別に再発率をみると C $15.4 \%$ ，A $30.8 \% ， T 23.1 \%$, D $11.1 \%$, S $20.8 \%$, Rs $41.4 \%$, Ra $34.3 \%$, Rb $39.6 \%$, P 55.3\%で, とくに肛門管癌で再発が高率であった(表 $1)$.

\section{2. 大腸癌の再発形式}

大腸癌の再発形式は局所再発 $31.0 \%$, 肝再発 $22.8 \%$, 複数臓器再発 $18.6 \%$, 腹膜再発 $9.0 \%$, 肺再発 $8.3 \%$, 雀径部リンパ節再発 $6.2 \%$, 骨再発 $3.4 \%$, 脳再発 $0.7 \%$ であった。結腸癌に㧊いては肝再発が $53.8 \%$ と最も多 く,ついで局所再発が $19.2 \%$, 腹膜再発が $15.4 \%$, 複

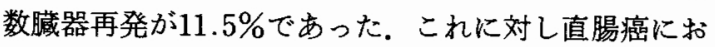

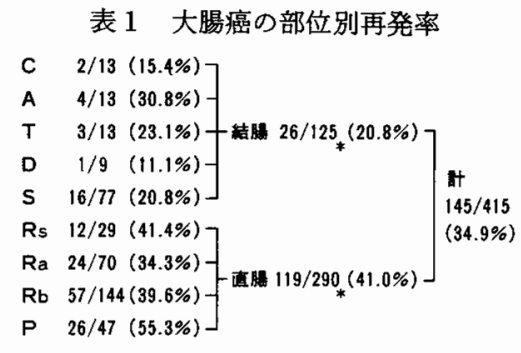

$$
* \mathrm{P}<0.01
$$

表 2 大腸癌の再発形式

\begin{tabular}{|c|c|c|c|c|c|c|c|c|c|}
\hline & If & $\operatorname{Den}^{*}{ }^{*}$ & 楼罢 & 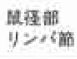 & 堛 & 鳀 & 蓝 & 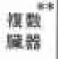 & st \\
\hline \multirow[t]{2}{*}{ 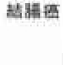 } & 14 & 5 & 4 & 0 & 0 & 0 & 0 & 3 & 26 \\
\hline & (53.8) & (19.2) & (15.4) & $(0)$ & $(0)$ & $(0)$ & $(0)$ & (11.5) & $(100)$ \\
\hline \multirow[t]{2}{*}{ 西胆量 } & 19 & 40 & 9 & 9 & 12 & 5 & 1 & 24 & 119 \\
\hline & $(16.0)$ & $(33.6)$ & $(7.6)$ & $(7.6)$ & $(10.1)$ & $(4.2)$ & $(0.8)$ & (20.2) & $(100)$ \\
\hline \multirow[t]{4}{*}{ it } & 35 & 45 & 13 & 9 & 12 & 5 & 1 & 27 & 145 \\
\hline & (22.8) & $\langle 310\rangle$ & $(9.0)$ & (6.2) & (8.3) & $(3,4)$ & $(0.7)$ & $(18.6)$ & (100) \\
\hline & & & & $\begin{array}{r}* \text { 手 } \\
\text { ま } \\
* *\end{array}$ & 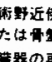 & \&日 & 公踾 & 等 登 충 & $\begin{array}{l}\text { 肪腹内 } \\
\text { t。 }\end{array}$ \\
\hline & & & & & 心他政 & 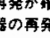 & 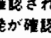 & & もの \\
\hline
\end{tabular}

いては局所再発が $33.6 \%$ 之最も多く, 複数臓器再発が $20.2 \%$, 肝再発が $16.0 \%$ ，肺再発が $10.1 \%$ ，単径部り ンパ節再発が $7.6 \%$, 腹膜再発が $7.6 \%$, 骨再発が $4.2 \%$ および脳再発が $0.8 \%$ はめた（表 2 ）。各再発形式ご とに原発部位をみると甪径部リンパ節再発は結腸癌で みられず，直腸では 9 例あり，このうち Rs と Raはな く $\mathrm{P} 8$ 例, $\mathrm{Rb} 1$ 例であった. 肺再発は直腸のみにみ られ（Rs 1 例， Ra 1 例， Rb 7 例，P 3 例)，とくに 下部のもので高率であった。骨再発は Rb 3 例, P 2 例にみられ, 脳再発は Rbに 1 例みられ, いずれも原発 宩が下部直腸および肛門管のものに限られていた，腹 膜再発は結腸（ $\mathrm{T}, \mathrm{S}$ ) および直腸 S 状部において比較 的高率にみられた（表 3).

\section{3. 大腸癌の再発時期}

再発時期は臨床的に再発が確認された時点とした。 再発時期の不明な 1 例を除く144例の再発確認の時期 は 1 年末満 $45.8 \%, 2$ 年末満 $81.2 \% ， 3$ 年末満 $89.5 \%$ であった.しかし， 5 年以後の再発も 7 例 $4.9 \%$ によ れた(図 1). 再発形式別に再発時期をみると，末ず結 腸癌では肝再発は平均 11.2 力, 局所再発は平均 17.2

表 3 原発部位と再発形式

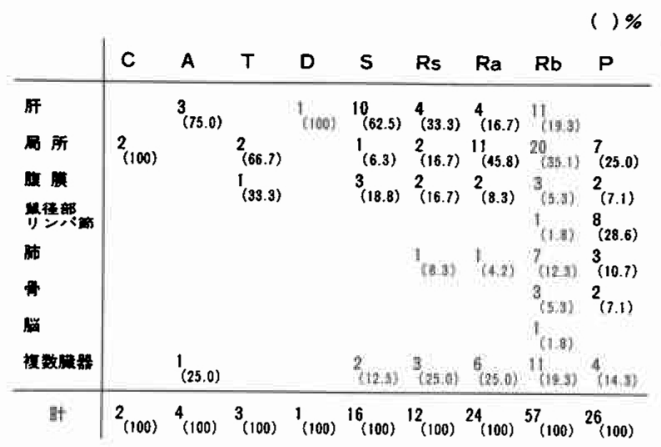

図 1 術後再発時期

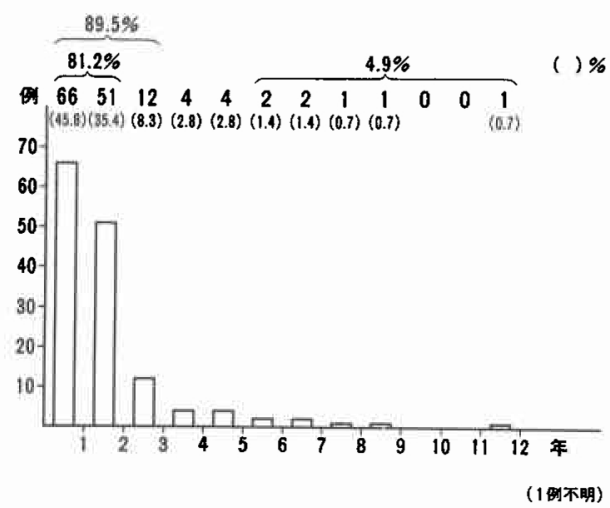


力月, 腹膜再発は平均 29.8 力, 複数蔵器再発は平均 15.7 月に確認され，5年 6 力月後に確認した腹膜再 発例の 1 例を除き全例が 3 年以内に再発が確認された (図 2). 直腸癌では肝再発は平均 17.5 力月, 局所再発 は平均 16.7 力, 単径部リンパ節再発は平均 12.9 力, 腹膜再発は平均 23.2 力, 肺再発は平均 33.5 力月, 複 数臓器再発は平均 15.1 力 月であり肺再発は比較的晚期 にみられた（図3）。

\section{4. 性別再発率}

結腸癌の性別再発率は男性 $21.3 \%$ (13/61)，女性 $20.3 \%(13 / 64)$ であり直腸癌では男性 $40.6 \%(71 / 175)$, 女性 $41.7 \%(48 / 115) て ゙ ，$ 結腸癌拈よひ直腸癌のいず れにも性別による再発率の羑はみられなかった。

\section{5. 年齢別再発率}

初回手術時の年龄別の再発率については，39歳以下 の若年群，40６9歳の中年群，70藏以上の高年群の 3 群に分けて検討した，大腸癌全体では若年群 $45.1 \%$ ， 中年群 $36.7 \%$, 高年群 $22.2 \%$ で高年群は若年群拉よび

\section{図2 結腸癌の再発時期}

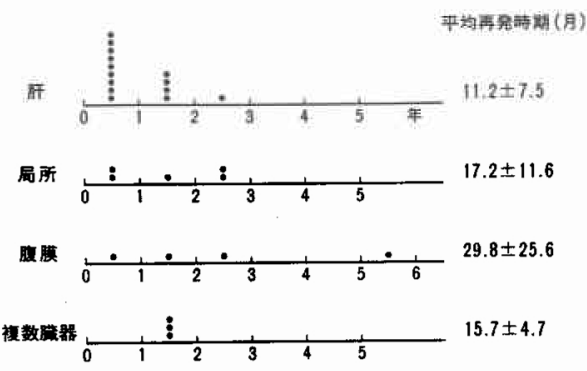

図 3 直腸癌の再発時期

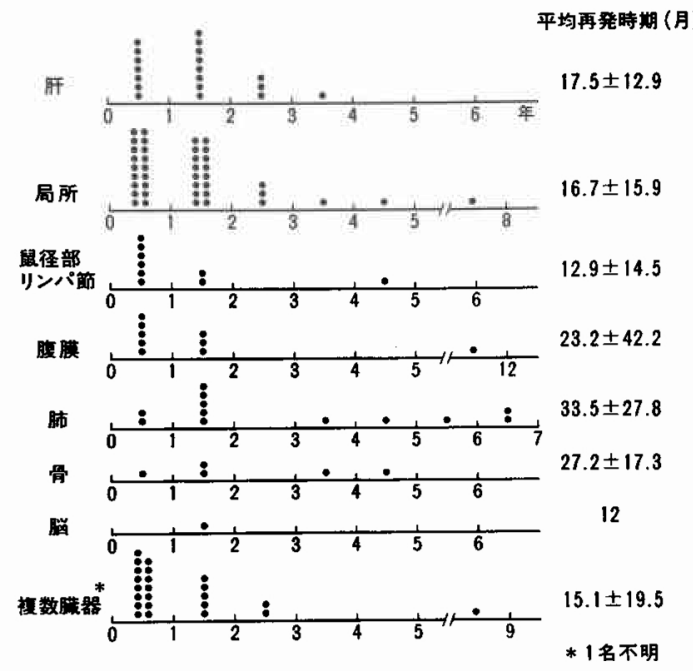

中年群と比べ有意に低い再発率であった，結腸癌再発 では若年群 $33.3 \%$, 中年群 $25.0 \%$, 高年群 $6.3 \%$ で高年 群で再発率が低く，若年群括よび中年群と高年群の間 には有意差が認められた。直腸癌再発では若年群 $47.6 \%$ ，中年群 $41.7 \%$, 高年群 $32.7 \%$ であり若年で高 率を示したが有意差はみられなかった（表 4 ）。

\section{6. 形態分類別再発率}

形態分類別の再発率は大腸癌全体では 0 型 $0 \%(0 /$ 17)，1型13.1\% (8/61)， 2 型38.3\% (97/253)， 3 型 $47.0 \%(31 / 66), 4$ 型 $0 \%(0 / 1), 5$ 型 $33.3 \%(3 / 9)$, 不明 $75.0 \%$ (6/8) であった。結腸癌では 0 型 0\%（0/ $6), 1$ 型 $13.0 \%(3 / 23), 2$ 型 $23.6 \%(17 / 72), 3$ 型 $27.8 \%$ $(5 / 18), 5$ 型 $25.0 \%(1 / 4)$, 不明 $0 \%(0 / 2)$ で, 直腸 癌では 0 型 $0 \%(0 / 11), 1$ 型 $13.2 \%(5 / 38), 2$ 型 $44.2 \%$ (80/181)， 3 型 $54.2 \%(26 / 48) ， 4$ 型 $0 \%(0 / 1) ， 5$ 型 $40.0 \%(2 / 5)$, 不明 $100 \%$ (6/6) であった。直腸癌 において 0 型は 2 型扰よび 3 型に比べ有意に再発率が 低く（ともに $\mathrm{p}<0.01 ） ，$ ま 1 型は 2 型および 3 型に 比べ有意に再発率が低かった（ともに $\mathrm{p}<0.01 ）$.

7. 深達度別再発率

深達度別再発率は大腸癌全体では $\mathrm{m}, \mathrm{sm} 0 \%, \mathrm{pm}$ $11.1 \%$, ss, $a_{1} 32.3 \%$, s, $a_{2} 42.2 \%, s_{1}, a_{1} 54.8 \%$ て あった。結腸癌では m, sm $0 \%, \mathrm{pm} 12.5 \%$, ss $34.6 \%$,

表 4 年齢別再発率

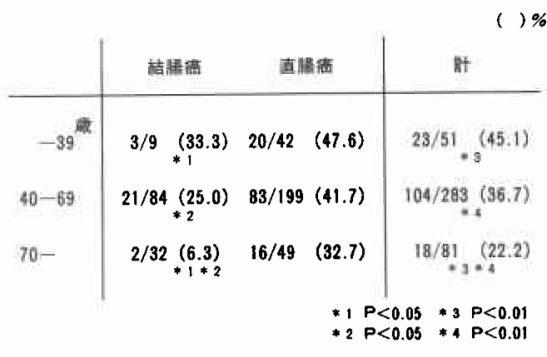

表 5 深達度別再発率

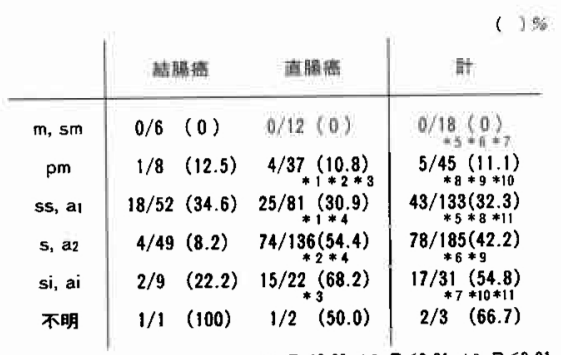

$* 1 P<0.05 * 5 P<0.01 * 9 P<0.01$ *2 $P<0.01 * 6 \quad P<0.01 * 10 P<0.01$ *3 $\mathrm{P}<0.01 * 7 \mathrm{P}<0.01 * 11 \mathrm{P}<0.05$ $4 P<0.01 * 8 \quad P<0.01$ 
$\mathrm{s} 8.2 \%, \mathrm{~s}_{\mathrm{i}} 22.2 \%$ で, 直腸癌では $\mathrm{m}, \mathrm{sm} 0 \%, \mathrm{pm}$ $10.8 \%$, ss, $\mathrm{a}_{1} 30.9 \%, \mathrm{~s}, \mathrm{a}_{2} 54.4 \%, \mathrm{~s}_{\mathrm{i}}, \mathrm{a}_{1} 68.2 \%$ で あった。壁深達度の進行とともに再発率は増加するが 直腸癌でこの傾向は顕著であり $\mathrm{pm}$ とs, $\mathrm{a}_{1}, \mathrm{pm}$ と $\mathrm{s}$, $\mathrm{a}_{2}, \mathrm{pm}$ と $\mathrm{s}_{1}, \mathrm{a}_{1}$ および $\mathrm{ss}, \mathrm{a}_{1}$ と $\mathrm{s}, \mathrm{a}_{2}$ の各再発率の間に 有意差があった（表 5 ）。

\section{8. リンパ節転移の程度と再発率}

リンパ節転移の程度別にみた再発率は大腸癌全体で は $\mathrm{n}_{0} 16.0 \%, \mathrm{n}_{1} 43.4 \%, \mathrm{n}_{2} 67.2 \%, \mathrm{n}_{3} 86.7 \%$ であっ た. 結腸癌では $\mathrm{n}_{0} 14.1 \%, \mathrm{n}_{1} 21.6 \%, \mathrm{n}_{2} 42.9 \%, \mathrm{n}_{3}$ $50.0 \%$ で, 直腸癌では $\mathrm{n}_{0} 17.0 \%, \mathrm{n}_{1} 52.9 \%, \mathrm{n}_{2} 74.0 \%$, $\mathrm{n}_{3} 92.3 \%$ あった。結腸癌, 值腸癌ともにリン八節転 移の進行とともに再発率は増加した。結腸癌では $\mathrm{n}_{0}$ と $\mathrm{n}_{2}$ の間で有意差があり直腸癌では $\mathrm{n}_{0}$ と $\mathrm{n}_{1}, \mathrm{n}_{2}, \mathrm{n}_{3}$ との 間， $\mathrm{n}_{1}$ と $\mathrm{n}_{2}, \mathrm{n}_{3}$ との間でいずれも有意差が認められた。 リンパ節転移陰性例では結腸癌と直腸癌で再発率に違 いはみられなかったが，リンパ節転移陽性例ではいず れの群でも直腸癌の方が再発率が高く, このうち $\mathrm{n}_{1}$ 群 については有意差があった（表 6 ）。

\section{9. stage 別再発率}

stage 別の再発率は大腸癌全体では I $0 \%$, II $21.9 \%$, III $42.3 \%$, IV $71.2 \%$ あった. 結腸癌では I $0 \%$, II $17.5 \%$, III $20.5 \%$, IV $46.2 \%$, 直腸癌では I
0\%, II 24.5\%, III 52.7\%, IV 76.7\%であり stage の進 行とともに再発率は増加した。結腸癌では stage IVは I, II，IIIのいずれと比較しても有意に高い再発率で あった。また直腸癌でも各 stage 間で有意差が認めら れた（表 7 ).

\section{Dukes 分類別再発率}

Dukes 分類別の再発率は, 大腸癌全体では Dukes A 0\%, Dukes B 21.3\%, Dukes C 54.2\%であった. 結 腸癌では Dukes A 0\%, Dukes B 16.4\%, Dukes C $28.3 \%$, 直晹癌では Dukes A 0\%, Dukes B 24.2\%, Dukes C 63.5\%であった. 直腸癌の Dukes C と Dukes A, Dukes Bの再発率の間, 拉よび Dukes B と Dukes Aの再発率の間には有意差が認められた（表 8).

\section{1. 病理組織型別再発率}

組織型別にみた再発率は大腸癌全体では高分化腺癌 $31.1 \%$, 中分化腺癌 $49.1 \%$, 低分化腺癌 $37.5 \%$, 粘液 癌 $38.1 \%$, 扁平上皮癌 $71.4 \%$ であった。結腸癌では高 分化腺癌 $23.2 \%$, 中分化腺癌 $17.6 \%$, 低分化腺癌 $28.6 \%$, 粘液癌 $12.5 \%$ で, 直腸癌では高分化腺癌 $34.1 \%$ ，中分化腺癌 $63.9 \%$ ，低分化腺癌 $44.4 \%$ ，粘液 癌 $53.8 \%$, 扁平上皮癌 $71.4 \%$ であった．結腸癌では組 織型による再発率の違いがみられないのに対し直腸癌 では中分化腺癌, 粘液癌, 扁平上皮癌に比べ高分化腺
表 6 リンパ節転移程度別再発率

\begin{tabular}{|c|c|c|c|}
\hline & 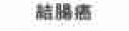 & 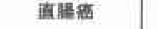 & ㅎt \\
\hline no & $10 / 71_{* 11}(14.1)$ & $\begin{array}{c}24 / 141(17.0) \\
+2+3: 4\end{array}$ & $\begin{array}{c}34 / 212(16.0) \\
+11+9+10\end{array}$ \\
\hline$n_{1}$ & $8 / 37,(21.6)$ & $\begin{array}{r}45 / 85(52.9) \\
* 2 * 5 * 6 * 7\end{array}$ & $\begin{array}{c}53 / 122(43,4) \\
* 8 * 11 * 12\end{array}$ \\
\hline $\mathrm{n}_{2}$ & $6 / 14(42.9)$ & $\begin{array}{c}37 / 50 \quad(74.0) \\
* 3 * 5\end{array}$ & $\begin{array}{c}43 / 64(67.2) \\
* 9 * 11\end{array}$ \\
\hline$n_{3}$ & $1 / 2 \quad(50.0)$ & $\begin{array}{c}12 / 13(92.3) \\
* 4 * 6\end{array}$ & $13 / 15 \underset{* 10 * 12}{(86.7)}$ \\
\hline 不明 & $1 / 1 \quad(100)$ & $1 / 1 \quad(100)$ & $2 / 2 \quad(100)$ \\
\hline & $\begin{array}{l}* 1 \quad P<0 . \\
* 2 \quad P<0 . \\
* 3 \quad P<0 .\end{array}$ & $\begin{array}{lll}05 & * 4 & P<0.01 * 7 \\
01 & * 5 & P<0.05 * 8 \\
01 & * 6 & P<0.05 * 9\end{array}$ & $\begin{array}{lll}P<0.01 & * 10 & P<0.01 \\
P<0.01 & * 11 & P<0.01 \\
P<0.01 & * 12 & P<0.01\end{array}$ \\
\hline
\end{tabular}

表 7 stage 別再発率

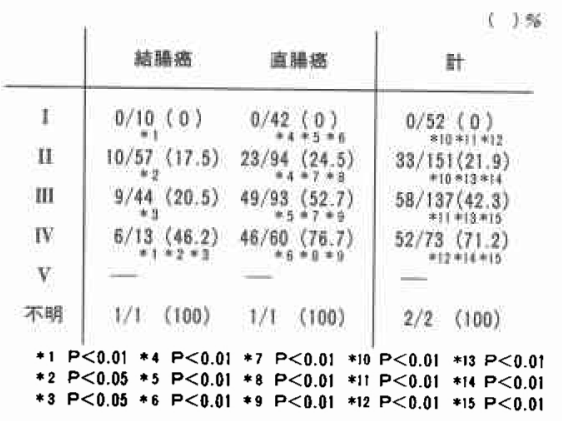

表 8 Dukes 分類別再発率

\begin{tabular}{|c|c|c|c|c|}
\hline & 结膈楆 & \multicolumn{2}{|c|}{ 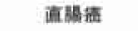 } & 部 \\
\hline Dukes A & $0 / 10(0)$ & \multicolumn{2}{|c|}{$\begin{array}{c}0 / 42(0) \\
-1=2\end{array}$} & $\underset{* 4 * 5}{0 / 52(0)}$ \\
\hline Dukes B & $10 / 61(16.4)$ & \multicolumn{2}{|c|}{$\underset{+1=8}{24 / 99}(24.2)$} & $34 / \underset{* 4 * 6}{160(21.3)}$ \\
\hline Dukes C & $15 / 53(28.3)$ & \multicolumn{2}{|c|}{$\begin{array}{c}94 / 148(63.5) \\
-2=3\end{array}$} & $\begin{array}{c}109 / 201(54.2) \\
* 5 * 6\end{array}$ \\
\hline 不明 & $1 / 1 \quad(100)$ & $1 / 1$ & $(100)$ & $2 / 2 \quad(100)$ \\
\hline & & \multicolumn{3}{|c|}{$\begin{array}{lll}* 1 & P<0.01 * 4 & P<0.01 \\
* 2 & P<0.01 * 5 & P<0.01 \\
* 3 & P<0.01 * 6 & P<0.01\end{array}$} \\
\hline
\end{tabular}

表 9 病理組織型別再発率

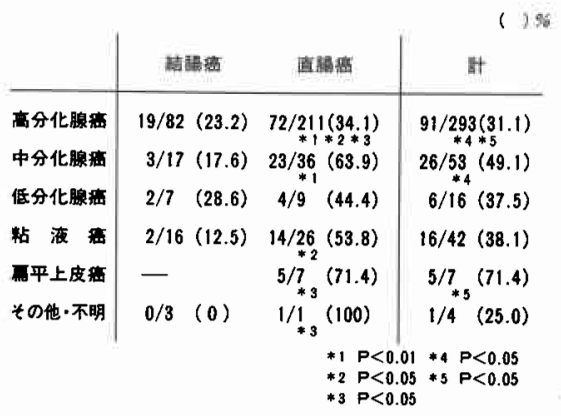


癌の再発率が有意に低かった（表 9 ）。

12. 組織型と再発形式

大腸癌再発例145例の再発形式と原発栄の組織型を 比較した。まず高分化腺癌では局所再発が $30.8 \%$, 肝 再発が $29.7 \%$, 複数葴器再発が $15.4 \%$ をめた。中分 化腺癌では局所再発 $(42.3 \%)$ 抢よび複数葴器再発 (23.1\%) が多く，粘液癌では腹膜再発 $(31.3 \%)$ 打よ び複数臓器再発 $(31.3 \%)$ が多く，また扁平上皮癌で は局所再発が60\%をしめた。 以上のように組織型によ り再発形式の頻度に違いがみられた。しかし, 結腸と 直腸には差はみられなかった（表10）。

\section{3. 脈管侵襲と再発率}

原発巣のリンパ管侵襲の有無により再発率を比較す ると大腸癌全体ではリンパ管侵擎陰性例（以下 ly (-) $29.1 \%$ ，リンパ管侵襲陽性例(以下 ly (十)) $42.8 \%$ でった. 結腸癌ではly(一) は21.2\%で, 直腸癌では ly (一) は $32.7 \%, 1 \mathrm{y}(+)$ は51.6\%であった。直腸癌でリンパ管侵蜲陽性例は陰 性例に比べ有意に再発率が高かった（表11）.

原発巣の静脈侵襲の有無で再発率を比較すると大腸 癌全体では静脈侵襲陰性例（以下 v (-)）29.9\%, 静 脈侵襲陽性例（以下 $\mathrm{v}(+)) 57.5 \%$ であった。結腸癌

\section{表10 病理組織型之再発形式}

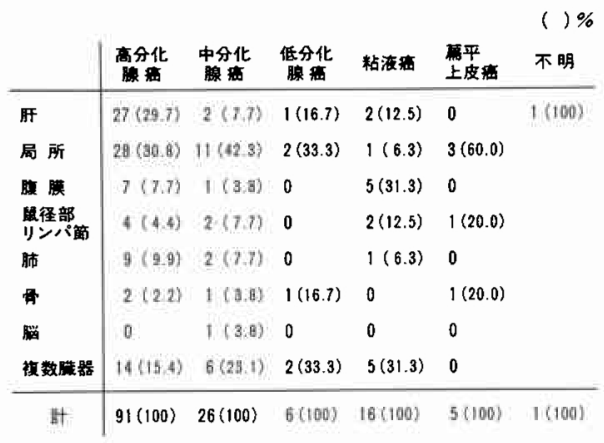

表11 脈管侵襲の有無と再発率

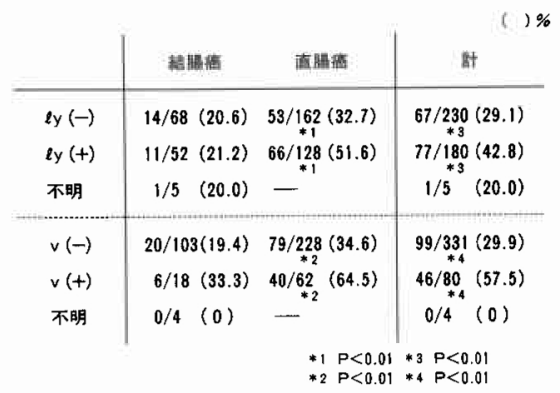

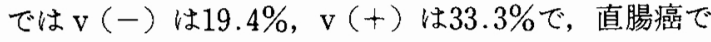
はv（一）は34.6\%，v（+）は64.5\%であった。静脈 侵襲陽性例は陰性例に比べ再発率が高く, 直腸癌では 有意差が認められた。

14. 再発発見確認またはその端緒となった方法

今回対象となった手術例では原則として術後 2 年以 内は 2 週間に 1 回， 3 年以内は 1 力に 1 回，5 年以 内は $3 \sim 6$ 力月に 1 回の外来診察を行い, 術後 3 年以 内は carcinoembryonic antigen (以下 CEA)などの腫 瘍マーカー測定を 1 年に 4 回ないし 6 回，肝掞よび骨 盤部の CT 検查 (昭和53年 3 月以前はシンチグラ フィー)を 1 年に 2 回ないし 3 回, また胸部 X 線検査, 注腸検查, 大腸内視鏡検査を年に 1 回以上必要に応じ 施行してきた。そこで, 最初に再発を発見した力法, または各再発を確認するため精査を加える端緒となっ たものについて検討した.

肝再発例33例では他にあまり症状がなく CT, シン チグラフィーの画像診断で初めて診断された例が11例 (33.3\%) と最も多く, CEA 值上昇によるものがこれに つぎ10例 (30.3\%) であった．局所再発45例では理学 所見によるもの17例( $37.8 \%), C E A$ 值上昇によるもの 9 例 $(20.0 \%)$, 疼痛などの自覚症状によるもの 8 例 (17.8\%)が多かった。腹膜再発13例では腹部膨满など の自覚症状が発見のきっかけとなるものが最も多かっ た。単径部リンパ節再発 9 例では理学所見によるるの が 6 例 $(66.7 \%)$ と最も多く, 肺再発12例では 9 例 $(75.0 \%)$ が胸部 X線検查によった。合計すると大腸癌 再発の発見の端緒となったものは理学所見40例 (27.6\%)，CEA 值上昇 29 例 (20.0\%), 自覚症状 24 例 $(16.6 \%), \mathrm{CT}$ 検査 11 例 $(7.6 \%)$, 胸部 $\mathrm{X}$ 線検査10例 （6.9\%）が多かった（表12）.

15. 大腸癌再発後生存期間

再発発見後の経過が不明な 2 例を除く143例のうち

表12 再発を発見した当初の方法

\begin{tabular}{|c|c|c|c|c|c|c|c|c|c|}
\hline & if & 属所 & 胫缕 & 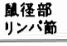 & 肺 & T & 脳 & 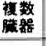 & it \\
\hline 自赏症状 & 1 & $B$ & 5 & 0 & 1 & 3 & 1 & 5 & $24(16,6)$ \\
\hline 理娄所見 & 7 & 17 & 3 & 6 & 1 & 0 & 0 & 6 & $40(27,6)$ \\
\hline CEA & 10 & 9 & 2 & 2 & 1 & 0 & 0 & 5 & $29(20.0)$ \\
\hline 胸部 X䋥 & 0 & 0 & 0 & 0 & 9 & 0 & 0 & 1 & $10(6.9)$ \\
\hline 内梘錘 & 0 & 1 & 0 & 0 & 0 & 0 & 0 & 0 & $1(0.7)$ \\
\hline シンチタラフィー & 7 & 0 & 0 & 0 & 0 & 0 & 0 & 1 & $8(5.5)$ \\
\hline$C \quad T$ & 4 & 5 & 0 & 1 & 0 & 0 & 0 & 1 & $11(7,6)$ \\
\hline 手 征 & 0 & 1 & 2 & 0 & 0 & 0 & 0 & 2 & $5(3.4)$ \\
\hline 不 明 & 4 & 4 & 1 & 0 & 0 & 2 & 0 & 6 & $17(11,7)$ \\
\hline it & 33 & 45 & 13 & 9 & 12 & 5 & 1 & 27 & $145(100)$ \\
\hline
\end{tabular}


生存例は 14 例で, 再発後の 5 年生存例は 3 例のみで あった。死亡例129例の平均生存期間は11.6力月であ り, た死亡例の5ち 114 例 $88.4 \%$ が 2 年末満で死亡し 経過は不良であった（図４）。

16. 再発巣切除の有無と再発後生存期間

再発例に対し再発巣の肉眼的治癒切除に準じた手術 が施行できたるのは肝再発11例, 局所再発19例, 肺再 発 5 例, 角径部リン八節再発 5 例, 腹膜再発 2 例, 脳 再発 1 例, 複数臓器再発 3 例の計 46 例であった。

当科に扣いて術後患者の CEA 測定を定期的に行ら ようになったのは昭和51年10月からで，同じくCT 検 查は昭和53年 4 月からである。そこで再発のスクリー ニングをたは確認のために CEA およびCTともま だ導入されていなかった昭和 47 年 1 月より昭和 51 年 9 月までに再発が確認されたものを前期群(27例)，CEA が導入された昭和 51 年 10 月より昭和 53 年 3 月までに確 認されたものを中期群(21例), CEA およびCTとも導 入された昭和53年 4 月以降に確認されたものを後期群 (97例)として各再発形式ごとに再発巣の切除率を比較 した.このらち切除率の向上がみられたすのは肝再発 であり，その切除率は前期 $0 \%$, 中期 $16.7 \%$, 後期

図 4 再発後の生存期間

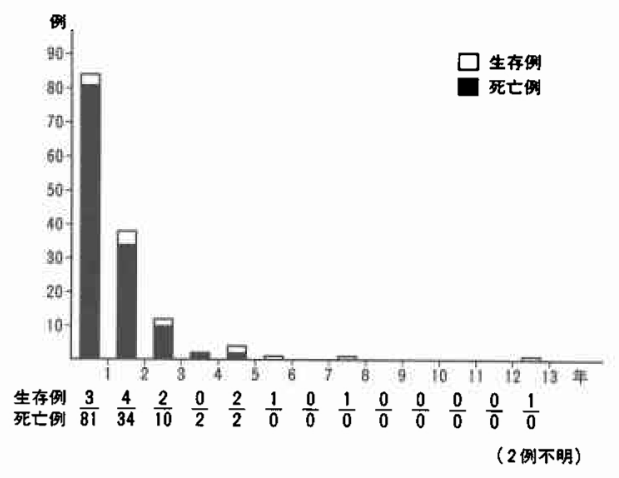

表13再発を確認した年代からみた再発巣切除率

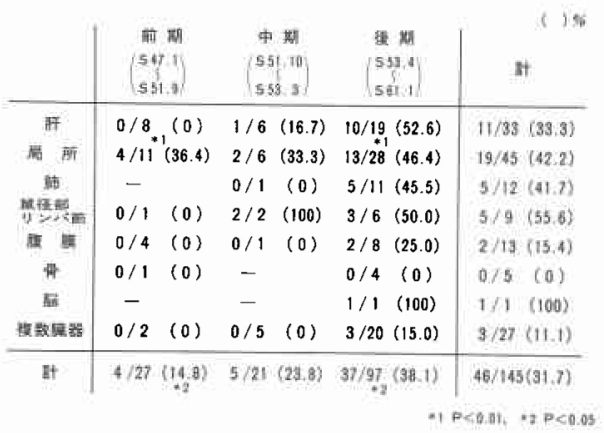

$52.6 \%$ であった（表13）.

再発発見の手段別に訮再発に対する切除率をみると 自覚症状や理学所見を発見の端緒としたものでは切除 できたものはなく, CEAによるスクリーニングの結果 発見された例では60.0\%，注注期的に行っている CTによる発見例では50.0\%が切除可能であった（表 14). 同様に, 局所再発に対する切除率をみると CEA によるスクリーニングの結果発見された例では $55.6 \%$, 定期的 CTによる発見例では $40.0 \%$ にあった。 これらは自覚症状による発見例での $25.0 \%$ おび理学 所見による発見例での $47.1 \%$ と比べ大きな差はみられ なかった。また年代別の局所再発巣切除率は，前期 $36.4 \%$, 中期 $33.3 \%$, 後期 $46.4 \%$, 肝再発でみら たような著しい向上はなかった（表15）。

つぎに再発巣切除の有無別に再発後の平均生存期間 を比較した。肝再発では切除群 34.8 力, 非切除群 10.2 力月, 局所再発では切除群 26.4 力月, 非切除群 8.8 力月, 肺再発では切除群 17.4 力月, 非切除群 19.7 力, 単径 部リンパ節再発では切除群14.2力月, 非切除群 8.5 力 月, 腹膜再発では切除群 20.0 力月, 非切除群 6.6 力月, 複数臓器再発では切除群 21.7 月, 非切除群 6.8 力月で あった。肺再発では切除群が平均生存期間が短い結果 となった。しかし，これは多くが比較的最近の症例で

表14 再発発見の手段と肝再発巣切除率

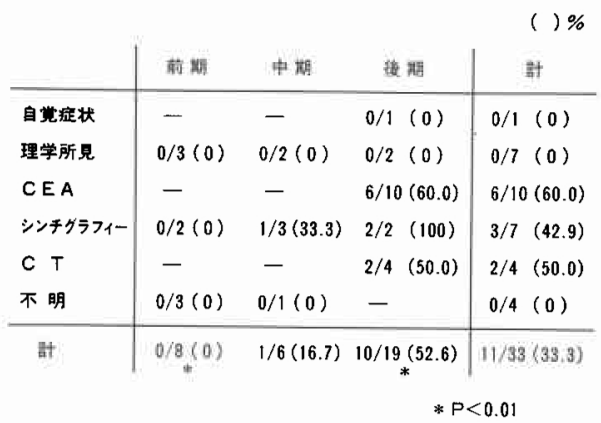

表15 再発発見の手段之局所再発巣切除率

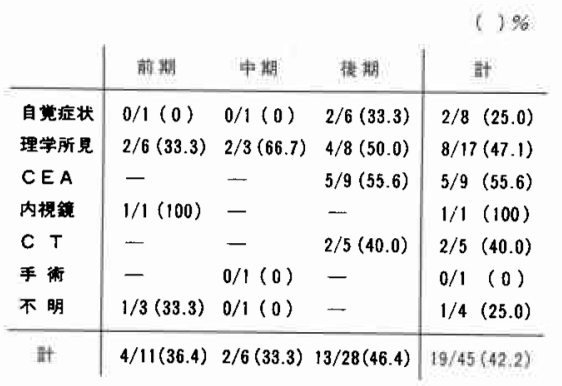


表16 再発巣の切除の有無と再発後生存期間（月数）

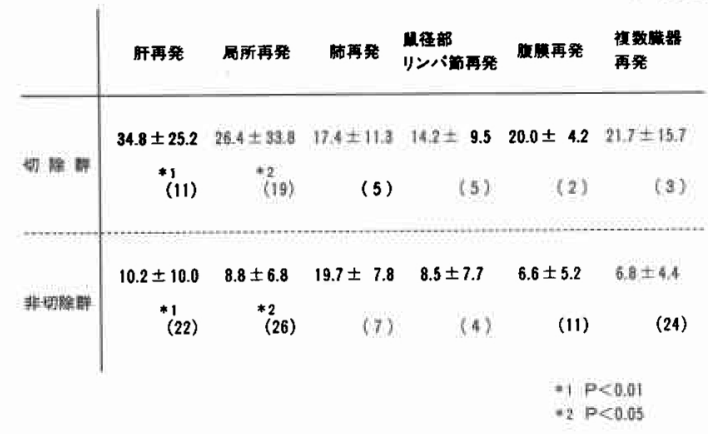

あるためで， 5 例中 4 例が生存中である，また，これ 以外の再発では切除できたるのの方が生存期間が長 かった。 とくに肝再発和よび局所再発に対する切除群 は非切除群に比べ有意の生存期間の延長がみられた (表16).

\section{III. 考 察}

大腸癌は手術療法により比較的良好な治療成績がも たらされる疾患とされるが, 非治癒手術例や治瘾手術 後の再発症例の経過は不良である. 非治瘉手術例や再 発例飞対する治療には多くの方法があり集学的治療が 応用されているが，その効果はまだ十分ではないし かし近年, 単独再発例の中には再切除により治癒した と考学られる症例があることが明らかにされた。ここ であらためて治癒切除後の再発の特徵などを知ること は, 再切除可能例の発見および他の有効な治療の早期 の開始を目的としてフォローアップを行ら上できわめ て重要である.

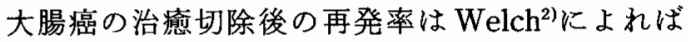
14.8\%, Malcolm³ によれば27\%, Törnqvist ${ }^{8}$ によれば 33\%で約30\%とするものが多い，また，冒頭で述べた 上らに再発の大部分は 3 年以内に招こるとされてい る. 自験例での再発率は 3 年以上経過例で $34.9 \%$ で あった。これらを部位別にみると直腸癌では $41.0 \%$ と 結腸癌の $20.8 \%$ に比べ有意に再発率が高く，部位によ る再発率の違いがみられた。とくに肛門管では $55.3 \%$ と高率であった。

再発形式については直腸癌掞上びS 状結腸癌は局所 再発をさたしやすく，結腸癌は肝再発をきたしやすい とするものが多い，北條副によれば直腸癌では $59 \%$ が 局所再発, S 状結腸癌では $58 \%$ が肝再発, その他の結 腸癌では病巣切除周辺の局所再発が一番多くみられる としている.今回の症例でも結腸癌では肝再発
$(53.8 \%)$, 直腸癌では局所再発 $(33.6 \%)$ が最も多く 見られた，腹膜再発は腹腔内に位置する横行結腸， S 状結腸, 直腸 S 状部に比較的高頻度にみられ, 単径部 リンパ節再発は肛門管, また肺再発も下部直腸および 肛門管で高頻度であり部位による再発形式の違いが認 められた。

大腸癌の再発時期は Welch ${ }^{2}$ によると12力月で $41 \%, 24$ 力月で $69 \% ， 36$ 力月で $82 \% ， 48$ 力で $89 \%$, 60 カ月で $94 \%$ であり，Deveney ${ }^{4}$ によると術後 2 年以 内に $78 \%$ ，また安富5によると術後 3 年以内に $85.3 \%$, 北條的によると局所再発の $85 \%$ が術後 2 年以内に再発 するとされる．今回の症例に扣いても2 年末満で $81.2 \% ， 3$ 年末満で $89.5 \%$ が再発して括り術後 3 年間 の経過観察はとくに重要であると考えられた.

年齢別に大腸癌の再発率をみると Malcolm ${ }^{33}$ とよる

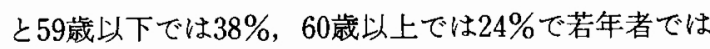
有意に再発率が高いとしている. Behbehani ${ }^{9}$ によると おなじ Dukes C 症例の比較でも40歳以下のものは 5 年生存率が有意に低いとしている．今回の症例でる同 様の傾向が認められたが，39歳以下の症例では高年者 に比べ高分化腺癌の占める割合が低く，ぬた stage IV 症例の占める割合が高年者に比べ有意に高いなどの背 景因子に違いがみられたことも考慮しなければならな い.

形態分類別にみると 0 型では再発例なく， 1 型では 結腸癌 $13.0 \%$, 直腸癌 $13.2 \%$ と比較的再発率は低いが, 直腸癌では 2 型 $44.2 \%, 3$ 型 $54.2 \%$ と高率であった。 4 型は治瘾手術となるものが少なく再発例はなかっ た。

深達度別にみると壁深達度の進行とともに再発率は 上昇するが，このことは結腸癌に比べ直腸癌の方が著 しく, s, $\mathrm{a}_{2}$ 以上の直腸癌では半数以上に再発がみられ た。

リンパ節転移の有無は大腸癌の再発に関係が深いと されているが，森谷 ${ }^{(0)}$ は直腸癌の治癒手術の全体の再 発率は $24 \%$ であり，このらち局所再発が半数近くを占 めるが，その70\%以上がリンパ節転移陽性例であると 述べている．とくに直腸癌ではリンパ節転移の有無が 予後を決定する大きな因子となると思われた。

stage 別の再発率は結腸癌, 直腸癌とも進行するに つれて上昇するがこの傾向は直腸癌で顕著であり， stage III では52.7\%, stage IVでは76.7\%に達した。

Dukes 分類別の再発率は結腸癌, 直腸癌とも Dukes A では $0 \%$ であったが，進行ととるに上㫒した，直腸 
癌でそれは著しくD Dukes C 症例の再発率がとくに高 率であった。

大腸癌の術後再発について, Malcolm ${ }^{3)}$, Rich $^{111}$ は組 䅧型別にみると低分化なものほど再発率が高い傾向が あるとしている，今回の症例では結腸癌では組織型に よる再発率の違いが見られなかったのに対し, 直腸癌 では高分化腺癌に比べ中分化腺癌, 粘液癌, 扁平上皮 癌は有意に再発率が高いことが注目された。低分化腺 癌は 9 例にすぎないが再発率は高分化腺癌と比べ高值 を示した。

脈管侵襲の有無でみると, 直腸癌ではリンパ管侵襲 および静脈侵襲とも陽性のものではこれらが陰性のも のに比べ有意に再発率が高かった。

以上のように大腸癌の再発の危険性掞よび再発形式 は原発部位, 進行度, 組織型などからある程度推測で きると考えられた。しかし個々の症例はこれらの因子 が組み合わさったものであり，さらに多変量解析など を用いた検討も必要である ${ }^{12)}$.

さて, 大腸癌の術後の経過観察中，ぞんな検査をど のよ5に行えば効率よく，早期に再発が発見できるか を明らかにすることはさわめて重要である．1973年の Welch ${ }^{2)}$ 報告によれば再発例の $85 \%$ は発見時に有症 状であるとしている. 1984年の Deveney4)の報告によ れば再発例の $48 \%$ 掂状か理学的検査が再発発見の手 がかりになったとしている。最近では CEA 值や肝機 能検査值でフォローアップすることにより無症状な症 例の中に切除可能な再発例が見いだされるとする報

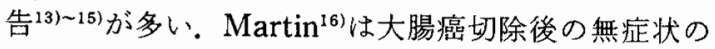
CEA 上昇例146例に second-look operation を行い 139例 (95\%) に再発がみられ81例 (58\%) が切除可能 であったと述べている。自験例では再発発見の端緒と なったものは理学所見 $27.6 \%$, CEA $20.0 \%$, 自覚症状 $16.6 \%$ が多かった。 そして,これらは CEA や画像診断 を行らようになった前と後の年代による違いがみられ た.すなわち CEA 測定, CT 検査がルーティーン化し た昭和53年 4 月以後の症例では肝再発, 局所再発の過 半数がこれらの検查の結果が精査の端緒となって発見 され，またこれによる再発巣の切除率の向上がみられ た。そして，この事実はとくに肝再発で明らかであっ た、また肝再発で切除できたものはいずれもフォロー アップ中, 無症状のうちに行った CEA 測定またはCT などの画像診断が発見の端緒であった。これに対し， 局所再発の切除率はこれらの検査が行われるように なっても向上は著しくなかった。これは局所再発例の
CEA 上昇率が緩徐であり ${ }^{1415)}$ ，また CTにおいても初 期の再発巣では症痕組織, 周囲組織との区別がしばし ば困難なためと思われる。このように CEA およびCT は大腸癌の肝再発の早期発見および切除による治療成 績の向上にとくに貢献すると考えられるが，それでむ 約半数は切除不可能な状態で発見されており，さらに 精度の高い再発の診断方法の開発が望まれる.

再発例の予後に関しては Welch ${ }^{21}$ は再発発見後の平 均生存期間は11カ月であり，このうち治癒切除ができ たものにかぎると平均33力月であったとしている。 た, Martin ${ }^{16)}$ は多数の無症状の CEA 上昇例に second-look operation を施行したが，再発切除例の 5 年生 存率は $23.9 \%$ であったと述べている，自験例では再発 啳の 5 年生存は 3 例で, 内訳は $\mathrm{S}$ 状結腸切除後 5 力月 の吻合部再発に対し再切除を施行した症例（12年10力 月生存中), 直腸低位前方切除後10カ月の肝転移に対し 肝右葉後区域切除を施行した症例（7年 2 力月生存 中), およびS 状結腸切除後10カ月の肝転移に対し肝右 葉切除十左葉部分切除を施行した症例（5年 5 力月生 存中）であった，再発死亡例129例の平均生存期間は 11.6 月であり, 木た, 死亡例のうち $88.4 \%$ 2 年末 满で死亡し経過は不良であった。再発巣の切除の有無 で再発後の生存期間をみると肝転䅂および局所再発に 対する切除例では平均 34.8 力および26.4力月で非切 除例の平均 10.2 力月扰よび8.8力月に比べ有意に良好 であった．他の形式による再発でも切除例では生存期 間が延長していると考兄られるものが多かったが有意 差はなかった。

大腸癌の治癒手術では, 初回手術時の臨床病理学的 な諸因子をよく検討し，必要かつ十分な切除を行って 再発を極力防止することが最も重要である。しかし， このようにしてる再発をなくすことは困難であると思 われ, 再発巣の早期発見およびその切除または他の治 療により治療成績を向上させることにも努める必要が ある. その成績をさらに良くするには現在のところ腫 場マーカー測定や画像診断などによる定期的なフォ ローアップを行い早期に再発を診断することが重要で あり, 今後さらによい診断, 治療法の開発に向かって 研究が必要である。

\section{まとめ}

1. 大腸癌の治癒手術後 3 年以上経過例の再発率は 結腸癌 $20.8 \%$, 直腸癌 $41.0 \%$ であった。

2. 再発時期は 2 年末満 $81.2 \%, 3$ 年末満 $89.5 \%$ で あった。 
3. 進行度とともに再発率は增加するが, 直腸癌のリ ンパ節転移陽性例では $63.5 \%$ と高率であった。

4. 結腸癌では組織型により再発率に差はみられな かったが，直腸癌では高分化腺癌 (34.1\%) に比べ中 分化腺癌 (63.9\%), 粘液癌 $(53.8 \%)$, 扁平上皮癌 (71.4\%) の再発率は有意に高かった。

5. CEA およびCT の導入により，とくに肝再発の 切除率は $52.6 \%$ に達し, 治療成績の向上がみられた。

6. 現在末での再発後の 5 年生存例は 3 例のみで あった。

7. 再発死亡例 129 例の平均生存期間は11.6力月で経 過は不良であったが，再発巣の切除により非切除例に 比べ生存期間が延長したと考えられる症例るみられ た。

\section{文献}

1）高橋 孝, 池 秀之, 池田孝明汪か：腸癌. 日臨 41(臨増)：1369-1382，1983

2) Welch JP, Donaldson GA: Detection and treatment of recurrent cancer of the colon and rectum. Am J Surg 135: 505-511, 1973

3) Malcolm AW, Perencevich NP, Olson RM et al: Analysis of recurrence patterns following curative resection for carcinoma of the colon and rectum. Surg Gynecol Obstet 152:131 $-136,1981$

4) Deveney KE, Way LW : Follow-up of patients with colorectal cancer. Am J Surg 148: 717 $-722,1984$

5）安富正幸, 村井紳浩, 進藤勝久ほか：結腸直腸癌再 発とその対策。癌の臨 $19: 638-644,1973$

6）北條慶一：大腸癌の治療成績の向上と今後の課 題. 手術 $38: 557-569,1984$

7）大腸癌研究会編：臨床 . 病理大腸癌取扱い規䄪. 第
4 版, 東京, 金原出版, 1985

8) Törnqvist A, Ekelund G, Leandoer L: The value of intensive follow-up after curative resection for colorectal carcinoma. Br J Surg $69: 725-728,1982$

9) Behbehani A, Sakwa M, Ehrlichman R et al: Colorectal carcinoma in patients under age 40. Ann Surg 202:610-614, 1985

10）森谷冝晧：進行大腸癌に対する集学的治療。外科 診㞠 $25: 1146-1155,1983$

11) Rich $T$, Gunderson LL, Lew $R$ et al: Patterns of recurrence of rectal cancer after potentially curative surgery. Cancer 52:1317-1329, 1983

12）过仲康伸, 松島 誠, 大見良裕法か：大腸癌根治手 術例の術前血中 CEA 值と治療成績との関俰。医の あゆみ $126: 251-254,1983$

13) Minton JP, Hohen JL, Gerber DM et al: Results of a 400-patient carcinoembryonic antigen second-look colorectal cancer study. Cancer 55:1284-1290, 1985

14) Staab HJ, Anderer FA, Stumpf E et al: Slope analysis of the post operative CEA time course and its possible application as an aid in diagnosis of disease progression in gastrointestinal cancer. Am J Surg $136: 322-327,1978$

15) Wanebo HJ, Sterns M, Schwarts MK: Use of CEA as an indicator of early recurrence and as a guide to selected second-look procedure in patients with colorectal cancer. Ann Surg 188 : 481-492, 1978

16) Martin EW Jr, Minton JP, Carey LC: CEAdirected second-look surgery in the asymptomatic patients after primary resection of colorectal carcinoma. Ann Surg 202:310 $-317,1985$ 